\title{
Analysis of Influence Factors of Electric Submersible Pump Performance in $\mathrm{X}$ Oilfield
}

\author{
Ren Xidong ${ }^{1}$, Meng Fanyuan ${ }^{2}$, Tian Yuming ${ }^{2}$, Du Chunyu ${ }^{2}, \mathrm{Xu} \mathrm{Jialiang}^{2}$ \\ ${ }^{1}$ (College of Petroleum Engineering, Northeast Petroleum University, Daqing 163318, China) \\ ${ }^{2}$ (College of Petroleum Engineering, China University of Petroleum (Beijing), Beijing 102249, China)
}

\begin{abstract}
The performance analysis is the key to guarantee the normal work of the electric submersible pump. According to the collection and statistics of working condition and fault types of electric submersible pump in X Oilfield, the influence factors of pump performance was analyzed, including drilling quality, pump type, air content and liquid level. The corresponding solutions were given at the same time, so as to provide a theoretical basis for the maintenance and fault diagnosis of electric submersible pump.
\end{abstract}

Keywords: -Electric submersible pump, X Oilfield, drilling quality, air content

\section{INTRODUCTION}

The electric submersible pump (ESP) has advantages of large displacement and high lift, which is widely used in high yield well, water well, deviated well and directional well ${ }^{[1-2]}$.In X Oilfield, ESP has become a very important production machinery and equipment with its unique advantages and characteristics ${ }^{[3]}$.However, with the increase of moisture content and liquid producing capacity year by year, the well failure is frequent, and the management difficulty is increasing gradually. So it is particularly important to analyze the affecting factors of ESP well performance. By analyzing the influencing factors of ESP well performance, the problems of ESP in the process of production can be discover and solve timely, avoiding downtime or inspection operations, which can extend the inspection cycle and reduce production cost.

\section{THE INFLUENCE OF DRILLING QUALITY ON ESP}

The dogleg during drilling is the main factor that influences the service life of ESP, and the influence of dogleg on the service life of ESP is mainly manifested in the following two aspects:

(1) In the process of installation, when pump units go through the curved hole, it will lead to the extrusion and friction between casing and pump units, generate additional load, and even scratch the cable. When the dog legs is too large, the pump units will stuck in the hole.

(2)When ESP is sent to the predetermined interval, due to the high demand of bending deflection, it will lead to the wear and tear of pump units if the requirements of deflection cannot be met. According to the comparison of ESP running situation in 35-2B oilfield and BZ25-1oilfield, it can be found that the influence of dogleg on ESP performance is obvious. The pump units of B14, B18, B24, B27, B28, B30, and B31 wells are affected by the dogleg degree in different degrees. The larger the dogleg of pump units is, the more times of inspection will be (Table 1).

Table 1 Dogleg of pump units

\begin{tabular}{c|c|c|c|c|c}
\hline $\begin{array}{c}\text { Well } \\
\text { number }\end{array}$ & $\begin{array}{c}\text { Location of pump } \\
\text { units } \\
(\mathrm{m})\end{array}$ & $\begin{array}{c}\text { Dogleg } \\
(\% / 100 \mathrm{~m})\end{array}$ & $\begin{array}{c}\text { Well } \\
\text { number }\end{array}$ & $\begin{array}{c}\text { Location of pump } \\
\text { units } \\
(\mathrm{m})\end{array}$ & $\begin{array}{c}\text { Dogleg } \\
(\% / 100 \mathrm{~m})\end{array}$ \\
\hline B14 & $1162.4-1174.8$ & $4.4-0.7$ & $\mathrm{~B} 18$ & $1197.1-1208.0$ & $3.01-5.78$ \\
\hline B19 & $1091.1-1095.2$ & $0.92-1.63$ & B20 & $1163.5-1173.5$ & 0.67 \\
\hline B21 & $1177.5-1179.8$ & $0.27-0.97$ & B24 & $1288.5-1297.9$ & $1.69-12.8$ \\
\hline B27 & $1108.2-1206.6$ & $2.02-4.76$ & B29 & $1174.8-1182.1$ & $2.85-1.32$ \\
\hline B30 & $1170.5-1140.0$ & 0.48 & B31 & $1196.1-1209.6$ & $0.68-11.9$ \\
\hline
\end{tabular}

Analysis results show that when the dogleg degree of pump units is greater than $3 \% / 100 \mathrm{~m}$, the operation of electric pump unit has the following characteristics:

(1)The starting current is much larger than that of normal wells.

(2) The current value is about 1.2 times that of the wells with the same production.

(3) When the dogleg degree of oil wells is larger than 5\%/100 m, the service life of ESP units is very short, or even cannot start (Table 2). 
Table 2 The contrast before and after pump inspection

\begin{tabular}{|c|c|c|c|c|}
\hline $\begin{array}{c}\text { Well } \\
\text { number }\end{array}$ & Time & $\begin{array}{c}\text { Power } \\
(\mathrm{kW})\end{array}$ & \begin{tabular}{|c} 
Range of production fluid \\
$\left(\mathrm{m}^{3} / \mathrm{d}\right)$
\end{tabular} & Faults and processing methods \\
\hline \multirow{2}{*}{ B33 } & $\begin{array}{c}\text { Before } \\
\text { inspection }\end{array}$ & 35 & $60-162$ & \multirow{2}{*}{$\begin{array}{l}\text { The motor burns down, and back } \\
\text { to normal after } 3 \text { tubing were lifted }\end{array}$} \\
\hline & $\begin{array}{c}\text { After } \\
\text { inspection }\end{array}$ & 46 & $170-284$ & \\
\hline \multirow{2}{*}{ B34 } & $\begin{array}{c}\text { Before } \\
\text { inspection }\end{array}$ & 37 & $70-167$ & \multirow{2}{*}{$\begin{array}{l}\text { The motor can't start, and } \\
\text { conditions improve after 4tubing } \\
\text { were lifted }\end{array}$} \\
\hline & $\begin{array}{c}\text { After } \\
\text { inspection }\end{array}$ & 46 & $170-288$ & \\
\hline \multirow{2}{*}{ B35 } & $\begin{array}{c}\text { Before } \\
\text { inspection }\end{array}$ & 46 & $80-168$ & \multirow{2}{*}{$\begin{array}{l}\text { The motor burns down, and back } \\
\text { to normal after } 3 \text { tubing were lifted }\end{array}$} \\
\hline & $\begin{array}{c}\text { After } \\
\text { inspection }\end{array}$ & 46 & $150-273$ & \\
\hline
\end{tabular}

\section{THE INFLUENCE OF PUMP TYPE ON ESP}

The matching of ESP type is the basic guarantee for the effective operation of pump units, including the matching of displacement and formation deliverability, the pump power and rated parameters of the motor ${ }^{[4-5]}$.

Pump efficiency is one of the most important parameters to analyze the working condition of $\operatorname{ESP}^{[6]}$.Some oil wells in BZ25-1 oil field have flowing ability due to sufficient formation energy. When the pump efficiency is greater than $100 \%$, the electric pump unit can also run as normal. Therefore, for ESP wells with flowing ability, using pump efficiency to analyze the operation condition of the electric pump is not typical.

Table 3 shows the statistics of ESP wells in X Oilfield, from which it can be found that when the pump efficiency is more than $100 \%$, the producing fluid level is between 200 to $400 \mathrm{~m}$, while the submergence depth is between 800 to $1200 \mathrm{~m}$. The large submergence depth will increase the displacement efficiency, which will affect the service life of electric pump units.

Table 3 Working condition of ESP wells in X Oilfield

\begin{tabular}{c|c|c|c|c|c|c}
\hline $\begin{array}{c}\text { Well } \\
\text { number }\end{array}$ & $\begin{array}{c}\text { Power } \\
(\mathrm{kW})\end{array}$ & $\begin{array}{c}\text { Delivery head } \\
(\mathrm{m})\end{array}$ & $\begin{array}{c}\text { Delivery } \\
\text { capacity } \\
\left(\mathrm{m}^{3} / \mathrm{d}\right)\end{array}$ & $\begin{array}{c}\text { Producing } \\
\text { capacity }\left(\mathrm{m}^{3} / \mathrm{d}\right)\end{array}$ & $\begin{array}{c}\text { Pump } \\
\text { efficiency } \\
(\%)\end{array}$ & $\begin{array}{c}\text { Submergence } \\
\text { depth }(\mathrm{m})\end{array}$ \\
\hline B3 & 76.4 & 1600 & 350 & 167.1 & 47.8 & 950 \\
\hline B4 & 48.9 & 700 & 400 & 372 & 93 & 1060 \\
\hline B8 & 40.3 & 1100 & 120 & 100.3 & 84 & 1130 \\
\hline B9 & 56 & 1100 & 200 & 220.4 & 110.4 & 1020 \\
\hline B10 & 46 & 1300 & 100 & 102 & 102 & 880 \\
\hline B12 & 74 & 1100 & 200 & 275.6 & 137.7 & 1150 \\
\hline B15 & 30 & 1000 & 65 & 76.9 & 118.2 & 1200 \\
\hline B17 & 46 & 1300 & 100 & 101.5 & 101.4 & 830 \\
\hline B21 & 35 & 1600 & 65 & 82.8 & 127.4 & 970 \\
\hline B24 & 53 & 1100 & 250 & 240.7 & 96.3 & 1020 \\
\hline B28 & 70 & 1100 & 250 & 306.1 & 122.4 & 1050 \\
\hline
\end{tabular}

\section{THE INFLUENCE OF AIR CONTENTON ESP}

According to the development characteristic of water flood oilfield, the bottom pressure will drop dramatically in the process of well production. When the bottom pressure is less than saturation pressure, the crude oil at the bottom of oil well and even inside the reservoir will produce air bubble, and contain large amounts of free gas in the well liquid, as a result, the gas volume that flows into the multistage electric submersible pump is significantly increased. However, when the volume is too large, the electric submersible pump will not be stable, and the displacement will decrease, which is harmful to the motor ${ }^{[7]}$.

Table 4 shows the fault statistics of ESP in X Oilfield. For the wells with same power and liquid producing capacity, the pump inspection period is much shorter in wells with high air/oil ratio, and the proportion of cable breakdown and motor burns up is more than $60 \%$. The air/oil ratio of B-7, B-9, and B - 20 well is about 70 , which is 3 to 4 times of that in other pumps. Therefore, the motor damage rate of the three wells is the highest. 
Table 4 Fault statistics of ESP in X Oilfield

\begin{tabular}{c|c|c|c}
\hline $\begin{array}{c}\text { Well } \\
\text { number }\end{array}$ & The unit manufacturer & Failure number & $\begin{array}{c}\text { Cable breakdown or motor } \\
\text { burn down }\end{array}$ \\
\hline B-7 & Tianjin, Shenyang, Daqing & 8 & 6 \\
\hline B-9 & Daqing, Shenyang & 5 & 3 \\
\hline B-20 & Tianjin, Shenyang & 5 & 3 \\
\hline
\end{tabular}

According to the analysis of fault statistics, this phenomenon is caused by the gas inside the insulation layer of cable or the clearance of a few strands. The frequent damage of the cable is mostly due to expansion, and the key to avoid expansion is to prevent the insulating layer from producing bubbles. Typically add a layer of woven fabrics on each core can achieve this goal ${ }^{[8]}$.As long as the woven fabrics do not lose strength under the condition of high temperature in deep well, it is a very efficient way. The new type of cable has a layer of steel sheath outside the insulating layer, which is used to prevent the expansion. The compact design can make the insulation layer of cable keep the original shape and strength during the work, and make sure that the lead sheath and steel sheath are not affected by high temperature in deep well.

\section{THE INFLUENCE OF LIQUID LEVELON ESP}

The producing fluid level of B-10 and B-12well is relatively low (Table 5), so that the electric submersible pump must be intermittent production, which affects the pump efficiency in production and decrease the current value, as a result, the working fluid level falls gradually and the gas goes into the pump. The solution is to complement formation energy timely or replace ESP with small-displacement ones.

Table 5 Data of producing fluid level

\begin{tabular}{c|c|c|c}
\hline $\begin{array}{c}\text { Well } \\
\text { number }\end{array}$ & $\begin{array}{c}\text { Measurement result } \\
(\mathrm{m})\end{array}$ & $\begin{array}{c}\text { Producing fluid level } \\
(\mathrm{m})\end{array}$ & \multicolumn{1}{c}{ Conclusion } \\
\hline B-10 & $864,875,886,865$ & 872.5 & The producing fluid level is low \\
\hline B-12 & $932,950,940,948$ & 942.5 & The fluid production force is poor \\
\hline
\end{tabular}

In addition to the above factors, there are some other reasons that will also affect the performance of ESP.

(1) The process design of pump inspection. The process design of pump inspection mainly includes geological design and construction design. The main content of geological design includes production history, analysis of oil well occurrence, construction objective, construction requirements and tubing notes, etc. The main content of construction design includes construction steps and matters needing attention in the process of operation, etc.

(2)Voltage fluctuation. The voltage fluctuation caused by electric submersible pump shuts down will cause the internal pressure of tubing change suddenly, and the solid impurities on tubing wall will fall off the wall due to the change of force direction. If the check valve on the pump is not closed well, it will cause the impurities flow into the pump, and the liquid in the tubing will flow backward, leading to the reversal of pump and motor. Only the motor overcomes the reverse torque force can it run forward, at this time, the high current will apply large current shock on the vulnerabilities of motor cable, making it breakdown caused by fever. Once start the pump, the downhole motor will exert 2.5-8 times of rated current on the motor, a few seconds later, the motor can run at a full speed of $2900 \mathrm{r} / \mathrm{min}$, and the motor is about 25 meters away from the pump body. When the motor torque increases suddenly, the mechanical shock damage on pump will become bigger, which is easy to cause the pump shaft break. High voltage may cause the following phenomena: produce great torque; twist off pump shaft and the spline; speed is higher than the normal speed; displacement increases; temperature lowers. Low voltage may cause the following phenomena: the torque reduces; the motor operation becomes harder, the start cycle extends; speed is lower than the normal speed; efficiency decreases, production declines; temperature increases.

(3)Gas escapes from casing. Electric pumping wells are equipped with downhole gas-liquid separator, and the liquid after separated from will flow into the annular space between tubing and casing, as the production of gas rising, the casing pressure will increase and lower the liquid level, leading to the pump under load and shutdown. The artificial deflated will cause the instability of container level, large fluctuations, and even make the process shut off. The working principle of constant pressure relief valve is that when the pressure achieves the set opening pressure, the casing pressure valve will open automatically. The set of pressure value should base on the specific situation of each well. Draws production and casing pressure curves, and then select the casing pressure under maximum yield, which is unstable in different periods. 


\section{CONCLUSION}

(1)The most important factor that affects the performance of ESP is drilling quality, and the dogleg during drilling is the main factor that influences the service life of ESP.

(2)Pump efficiency is one of the most important parameters to analyze the working condition of ESP. When the pump efficiency is larger than $100 \%$, the producing fluid level is between 200 to $400 \mathrm{~m}$, while the submergence depth is between 800 to $1200 \mathrm{~m}$. The large submergence depth will increase the displacement efficiency.

(3)When the bottom pressure is less than saturation pressure, the crude oil at the bottom of oil well and even inside the reservoir will produce air bubble, and contain large amounts of free gas in the well liquid, as a result, the gas volume that flows into the multistage electric submersible pump is significantly increased, leading to the decrease of displacement.

(4)Replenishing formation energy timely and replacing electric submersible pump with small-displacement ones can both reduce the influence of liquid level on electric submersible pump.

\section{Journal Papers:}

\section{REFERENCES}

[1] Sun Yuehua, Jian Xinglan. Study on safety estimation methods of the electric submersible pumping system [J].Oil Field Equipment, 2003, 32(5): 15-17.

[2] Nolen, K.B. Analysis of Electric Submersible Pumping Systems [J], SPE 16196, 1987.

[3] Pessoa. Experimental Investigation of Two-Phase Flow Performance of Electrical Submersible Pump Stages [J]. SPE71552, 2001.

[4] Sawatyn S J, Grames K N. The analysis and prediction of Electric Submersible Pump Failures in the Milne Point Field, Alaska [J]. SPE56663, 2011.

[5] Power L. Mechanics of an Electric Submersible Pump Failure Mode [J].SPE75295, 2002.

[6] Harun A F, Prado M G. A Simple Model to Predict Natural Gas Separation Efficiency in Pumped Wells [J]. SPE63045, 2003.

[7] Feng Ding, Zhu Hongwu, Xue Dunsong. Synthetic diagnosis model for electric submersible pump unit based on system analysis [J].Acta Petrolei Sinica, 2007, 28(1): 127-130.

[8] Zhang Hui. The Fault Analysis of Electrical Submersible Pump in High Temperature Oil Well [J].Equipment Manufacturing Technology, 2009, 11: 69-70. 